\title{
Creating new products and positionings for direct television sales through a strategic alliance of Internet portal and customer research
}

Received: 22nd February, 2001

\section{Samuel Rabino}

is Professor, Marketing Group at Northeastern University and Research Associate at Scuola Superiore di Studi Universitari e di Perfezionamento S. Anna, Pisa, Italy. He also lectures at Harvard University.

\section{Howard Moskowitz}

has worked for 23 years in marketing, 17 years as President of Moskowitz Jacobs Inc., a company in the business of product and concept screening, optimisations and sensory preferences segmentation.

\begin{abstract}
Developing products for the direct television market is different from conventional marketing procedures customarily used by marketers in the packaged goods industry. Direct marketing on television requires the use of infomercials, which provide extensive information. These infomercials are expensive to make and are designed to sell, rather than simply to create a brand image. Direct marketers have typically not been able to access high levels of consumer interaction. Recent availability of sophisticated Internet research methods has prompted marketers' interest, thanks to the cost-effectiveness of Internet research. This paper presents observations on the development of research programmes using conjoint analysis on the net, along with segmentation. The paper also outlines the integration of a research company's approach, facilitated by an opt-in portal, to service and to provide strategic advantage to a direct television marketer.
\end{abstract}

Professor Samuel Rabino College of Business Administration, Department of Marketing, Northeastern University, 202 Hayden Hall, Boston, Massachusetts, MA 02115-5000, USA.

Tel: +1 (617) 373 4565; Fax: +1 (617) 373 8366; e-mail:

srabino@lynx.neu.edu

\section{INTRODUCTION}

Practitioners have been aware of sophisticated market research tools for several decades, ${ }^{1,2}$ though of course their first applications were far less advanced ${ }^{3}$ than today's methods. Despite this, a large number of businesses are still unfamiliar with progressive research tools. These businesses are often entrepreneurial, or run by individuals who saw and seized a 'now or never' opportunity, foregoing formal market data-gathering systems and instead shooting from the hip. Often such businesses prescribe no set procedures for new product development, unlike most larger, better-established companies. ${ }^{4}$ Their operations are usually short on resources, and often make decisions based on intuition or slim data. ${ }^{5}$ Some of these entrepreneur marketers, however, recognise the need to better understand their customers, and have become increasingly approachable to researchers, 
and more inclined to develop efficient information collection plans. As a by-product of this refocus, advanced data collection and analysis procedures are migrating from academia, through the larger consumer packaged goods companies (which have traditionally been early adopters of such techniques), into the trade and the less research-proficient clientele.

Emerging technologies and better developed media enable more companies to sell their products and services directly to consumers, without the usual intermediaries. E-mail, the Internet and on-line services now complement traditional media such as print and broadcast, catalogues, direct mail and telephone marketing. These new electronic communication tools are utilised both to support marketing strategy and to gauge customer response. This new media can be used to make direct offers to existing customers and can also be employed to identify new prospects. Direct marketing provides a more accurate and timely way for companies to target their offers and to measure results. The Direct Marketing Association defines direct marketing as 'an interactive marketing system that uses one or more advertising media to effect a measurable response and/or transaction at any location'. 6 This definition emphasises a measurable response. From a practitioner's standpoint, the element of response time is particularly critical, especially when employing television as the communication medium. Vehicle costs (especially to the small firm), changing tastes and multiple offerings all contribute to make time, selling or feedback on reported sales, an even more important factor for the direct marketer. This is especially true in the case of the small entrepreneur.

This paper presents a case history of how a direct television marketer utilised a specific research procedure and developed a formal relation with both a research company and an Internet portal to deploy ongoing research.

\section{STEPS IN THE PROCESS: DEVELOPING A KNOWLEDGE- DRIVEN RESEARCH SYSTEM}

Step 1: recognition of the changing competitive frame

Step 2: the search for a partner in research and in respondent procurement

Step 3: the alliance as a system for development

Step 4: the application of an advanced statistical technique

Step 5: the discovery and use of segments in the population

Step 6: the timely adaptation of the results for infomercials

Step 7: the incorporation of the research approach as a platform to gain competitive dominance.

\section{STEP 1: RECOGNISING THE CHANGING COMPETITIVE FRAME AND REEXAMINING THE NEED FOR CONSUMER UNDERSTANDING}

Direct television marketing has become very competitive. QVC's success, combined with rapid feedback regarding offerings' successes and failures, has increased the number of infomercials. The cost for a selling effort on QVC or similar types of cable programmes remains undeniably expensive, however. An infomercial can cost up to $\$ 40,000$, and if it does not sell the product, it may prove a costly and ineffective investment. Direct television pioneering has been a learning experience, one that has yielded better and more efficient infomercials. At this point, infomercial 


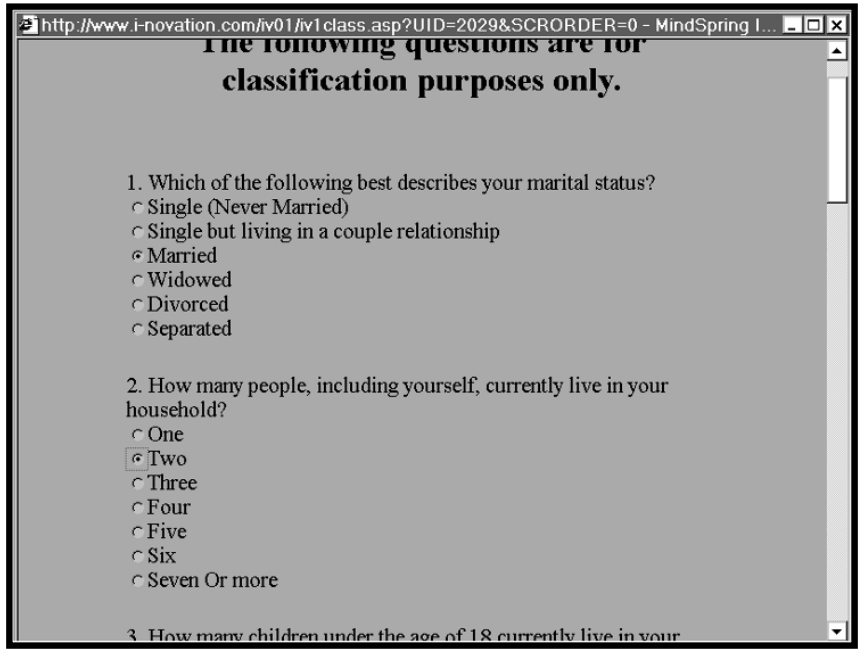

Figure 1 Classification screen

creators can usually intuitively feel out which products align well with this media outlet. Sources of public information tracking sales and consumer receptivity are not, however, readily available. Competition is not easily measured by traditional statistics such as sales and market share. Additionally, with direct television marketing, brand is not as important as specific product features. Many of the methodologies and measuring techniques used in mass marketing branded products are not transferable to direct marketing. Intrinsic brand value, for instance, is not as critical because emphasis is focused on presenting and demonstrating product features. ${ }^{7}$ Infomercial sales revenue directly measures success. ${ }^{8}$

\section{STEP 2: THE SEARCH FOR STRATEGIC PARTNERS}

The marketer needs to form a strategic partnership that facilitates the identification of potentially profitable products through research information availability. As noted earlier, direct television marketers are not frequent users of formal research databases and are not always aware of available data collection and analysis approaches. The research company that this paper follows began its search for prospective partners with a pool of would-be users, coupled with a few sources of low-cost consumer information. After a number of meetings, an Internet-provider partner was selected for its ability to recruit motivated respondents to take place in research programmes. The next focus was identifying the most appropriate research design for the project. Since the project's research goals were simply to identify and optimise winning products by weeding out weak ones, research design efforts were ambiguous. In an effort to clarify the search's goals, discussions were redirected toward establishing procedures to optimise product. The strategic alliance that emerged was a three-way partnership including an ultimate client (direct television marketer), a portal (pool of respondents) and the research company. The alliance offered conjoint measurement methods via the Internet, which would screen and then optimise new product ideas. 


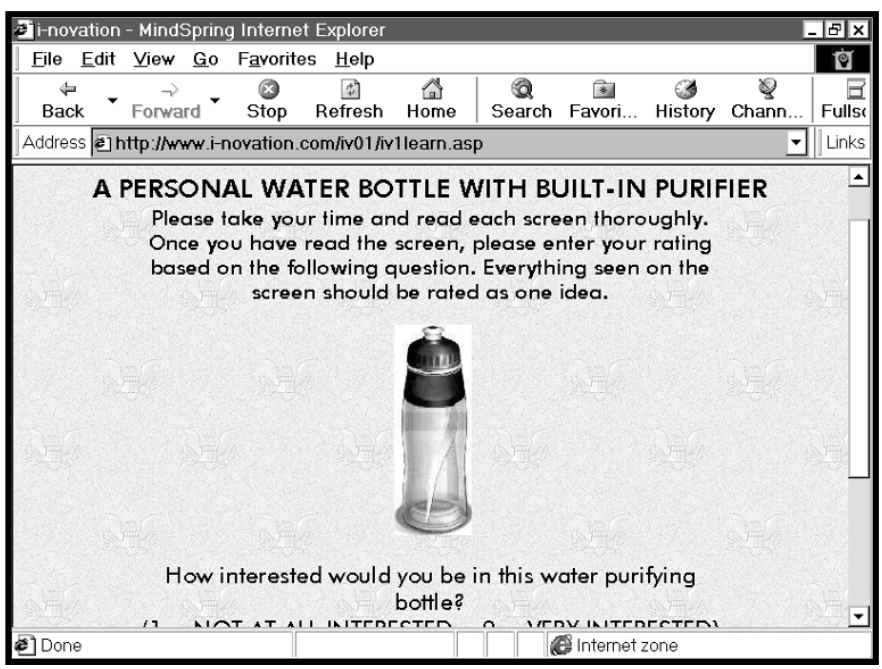

Figure 2 Orientation screen showing the type of product being evaluated

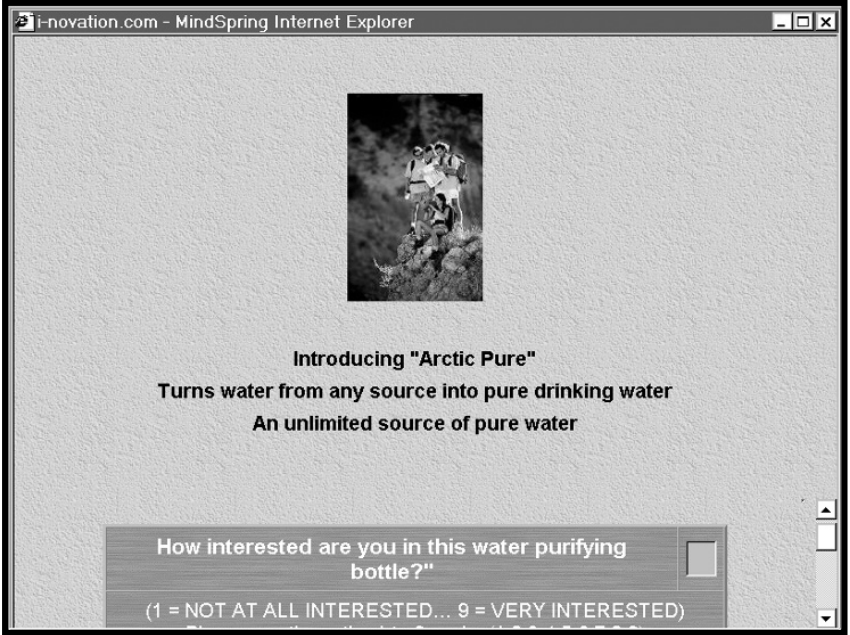

Figure 3 Example of a concept

\section{STEP 3: THE ALLIANCE AS A PLATFORM FOR DEVELOPMENT}

A key issue that kept cropping up was the marketer's desire to create a system for ongoing product development, rather than an ad hoc relationship. The marketer had already conducted spot research studies, but these did not establish a platform that could be continuously employed for future studies. An integral qualification of this partnership was a lengthy useful life span, which the alliance was indeed able to provide. This informal partnership established a streamlined testing environment where the marketer could introduce new ideas, participate in ideation sessions, test and optimise products and positioning and then relate findings to the research group. 
Table 1: Utility values for concept elements as estimated using dummy variable regression. Each number in the body of the table is the additive conditional probability that the concept will go from uninteresting to interesting, given the presence of the element

\begin{tabular}{lr}
\hline & Total \\
\hline & BASE SIZE: \\
CONSTANT: & 476 \\
The best elements & 6 \\
Removes germs, including almost all bacteria & 5 \\
Removes metals and chemicals, including lead and virtually all chlorine & 4 \\
Turns tap water into bottled water & 4 \\
Gives peace of mind by supplying clean, healthy water anywhere, anytime & 4 \\
Know your children will have a constant supply of fresh drinking water & -1 \\
The worst elements & -2 \\
Complements your active lifestyle & \\
Used by Olympic gold medallist to improve performance & \\
\hline
\end{tabular}

\section{STEP 4: IMPLEMENTING A COMPLEX RESEARCH PROCEDURE}

Often, conjoint measurement tasks take a long time to design, execute and understand. This high-level research technique was honed down to a short, three-session process, which led to increased throughput and new idea testing. These three sessions are outlined below.

Session 1: new product ideas were introduced and element-developing ideation was presented. ${ }^{9}$ These elements were then incorporated into the experimental design, using procedures already published. ${ }^{10}$

Session 2: a 12-minute online interview was conducted with respondents. Figures 1-3 present the interview materials as they actually appeared on the screen. The interview was open to any person defined as belonging to the appropriate consumer group. Respondent recruiting was left to the portal company, who incentivised participation through a points system. The results of the study were immediately processed to yield a model outlining the marginal or part-worth contribution of every element in the study. A consumer-estimated acceptance rating was also processed. The analysis was done by dummy variable regression analysis. ${ }^{11}$

Session 3: results were debriefed. Initial debriefing for the first project took about four hours. Subsequent debriefing required far less time and much shorter reports. Changes in debriefing time and client understanding indicated a steep learning curve. The nature of the questions changed, from early questions dealing with method and data interpretation, to later questions regarding data utilisation strategy and tentative product design evaluation. This evolved questioning process and the subsequent use of its results can be attributed to the relationship between the client and the research group.

An example of results appears in Table 1 , showing ranked elements in terms of overall ability to interest the customer. The base size of 476 consumers is relatively easy to obtain on the Web, if the researcher has a source of respondents and if those respondents can be motivated. The model is estimated through dummy variable regression analysis. ${ }^{12,13}$ The constant, 36, shows that 36 per cent of the respondents would be interested in the product, even if no elements were available. (For comparison purposes, coffee generates an additive constant of around $40,{ }^{14}$ whereas credit cards generate an additive constant around 20.) The additive constant is not directly developed, but rather estimated 
using regression analysis. The numbers to the right of the concept elements are utilities. These are the conditional probabilities that a concept will change from an indifferent rating (1-6) to an interesting rating (7-9), given the presence of the element in the concept.

A key discovery was the relatively narrow range of utility values. The maximum utility was 6 , the minimum -2 . This initial result pointed to one of two possibilities. Either the Web approach was not viable (and thus the strategic partnership would not hold) or the respondents were strongly segmented, so that the total panel data were actually disguising the data from radically different individuals.

Analysis of the raw data dispelled the initial conjecture that this was being caused by Web respondents' indifference. Only six of the respondents show no variation at all in their elements. (For comparison purposes, in a study evaluating the appeal of Vice President Gore, performed on the Web using the same method, the number of no variation respondents was 17 in 200 respondents). The flat appearance of the data had to be traced to some other reason. The most plausible reason was the existence of segments.

\section{STEP 5: THE UNCOVERING AND APPLICATION OF SEGMENTATION PROCEDURES}

A central benefit of a sophisticated research approach, such as conjoint analysis, is the ability to uncover segments in the population, and after doing so, identifying specific features and communications for these segments. Indeed, conjoint analysis attempts to determine the relative importance consumers attach to salient attributes and the utilities they attach to the level of those attributes. ${ }^{15}$ Segmentation research utilising conjoint analysis is not a new phenomenon; the platform has been popular with marketers and market researchers for more than 40 years. ${ }^{16,17}$ Given rapid advances in information technology, it has become imperative that segmentation be immediately 'actionable', since the direct response market comprises short-lived product offers. An applied segmentation procedure needs to go beyond theoretical constructs into specific prescriptions of what to do and what to say. One method of using segmentation based upon the relation of an individual's utilities to some underlying set of dimensions has proved particularly useful. ${ }^{18-20}$ That method of segmentation was applied to the study discussed here.

In direct response television marketing, segment recognition exists, but that recognition is based mainly upon the marketer's experience. Quite often there is little background in formal research and marketing, so that the segmentation the marketer uses is intuition-based. In the case of this study, the marketer began to internalise the segmentation over time, and instead of approaching the segmentation from a theoretical viewpoint, was able to understand the meaning of these segments from the data themselves. Table 2 shows the results of the segmentation, which revealed two key segments:

- segment 1: basically interested in the product (additive constant of 50), but little that one says will interest them much more

- segment 2: modestly interested in the product, but there are many elements that one could put into the concept that will convince these individuals to purchase the product. The elements deal with purity, recognised authority and value for money. 
Table 2: Utility values for winning elements for the two key segments

\begin{tabular}{|c|c|c|c|c|}
\hline & & Total & Seg 1 & Seg 2 \\
\hline & $\begin{array}{l}\text { BASE SIZE: } \\
\text { CONSTANT: }\end{array}$ & $\begin{array}{l}476 \\
36\end{array}$ & $\begin{array}{r}138 \\
50\end{array}$ & $\begin{array}{r}193 \\
28\end{array}$ \\
\hline \multicolumn{5}{|l|}{ Segment 1: Interested, basic idea of freshness } \\
\hline Safer than bottled water, which may contain bacterial buildup & & 1 & 6 & 0 \\
\hline $\begin{array}{l}\text { Removes metals and chemicals, including lead and virtually all } \\
\text { chlorine }\end{array}$ & & 5 & 4 & 11 \\
\hline Segment 2: Purity seekers & & 1 & 4 & 1 \\
\hline Removes germs, including virtually all bacteria & & 6 & 3 & 13 \\
\hline Turns tap water into bottled water & & 4 & -1 & 12 \\
\hline Turns water from any source into pure drinking water & & 3 & -6 & 12 \\
\hline $\begin{array}{l}\text { Removes metals and chemicals, including lead and virtually all } \\
\text { chlorine }\end{array}$ & & 5 & 4 & 11 \\
\hline Used by the Red Cross in disaster areas & & 3 & -3 & 11 \\
\hline A 20 oz bottle costs $\$ 9.99$, which is good for 320 refills & & 2 & -6 & 11 \\
\hline A 16 oz bottle costs $\$ 19.99$, which is good for 1,000 refills & & 1 & -11 & 11 \\
\hline Gives peace of mind by supplying clean, healthy water anywhere & & 4 & 2 & 10 \\
\hline A 20 oz bottle costs $\$ 14.99$, which is good for 850 refills & & 3 & -2 & 10 \\
\hline $\begin{array}{l}\text { Be confident that you will always have a clean water supply } \\
\text { when travelling }\end{array}$ & & 3 & -3 & 10 \\
\hline Exceeds the minimum EPA standards for water quality & & 2 & -6 & 10 \\
\hline
\end{tabular}

\section{STEP 6: THE TIMELY ADOPTION OF THE RESULTS FOR INFOMERCIALS}

One measurement of the effectiveness of the marketing research process is the ability to articulate its findings in a succinct fashion that addresses its original objectives. In traditional consumer packaged goods marketing, a successful research project will yield a positioning platform that is easily communicated to the desired target market. In this context, advertising and promotion are used to enhance earlier decisions regarding the value proposition of the product. ${ }^{21}$

Traditional consumer package goods (eg cereal, toothpaste) typically undergo minimal changes in core physical product attributes. Market performance is largely supported by repeatedly communicating a clear positioning statement, through both advertising and promotion.

Trying to appeal to consumers in a direct market (especially a 30-minute infomercial) is quite a different task. The marketer attempts to close sales in a very short period of time. It is imperative, therefore, to engage the viewer with a flow of phrases and visual stimuli that meet consumers' wants and needs within this finite period. Therefore, the product developer is pressured to generate rapidly and inexpensively designs or platforms that are easily translated into attractive products with clear value propositions.

For direct television marketing, the sales effort is designed to be effective within a time constraint. Marketing's objective is to identify the particular phrases and pictures that will sell the product during this finite period. Therefore, the developer's objective is to obtain results quickly and inexpensively, and to use them to create the product and its supporting advertising. In contrast to a comprehensive agenda, which is associated with supporting advertising. Unlike traditional consumer good companies, the direct marketer is not looking for insights into a limited product; rather, the marketer looks for a database that can feed ideas on a timely basis, as well as ways to communicate these ideas to the buyer. Meeting critical deadlines is essential. The direct marketer must be able to perform this type of research rapidly, to identify salient points 
with almost a production-line mindset. Researchers working on studies for direct sales, therefore, need to distil results to a simple set of recommendations and to report these in a timely fashion, because the direct marketer will then immediately incorporate them into the infomercial. What is most important here is the gradual change in the direct marketer's point of view, from an 'intuition based' to 'intuition plus data' based framework.

\section{STEP 7: THE INCORPORATION OF THE RESEARCH APPROACH AS A STANDARD METHOD TO GAIN COMPETITIVE DOMINANCE}

The final stage in the development of this research/marketing paradigm consists of the incorporation of the process as a standard method for early stage identification of potential products, and the optimisation of features. ${ }^{22}$ Excellent descriptions of the mathematical model expressing the fundamental relationship between attributes and utility in conjoint analysis have been rigorously covered elsewhere. $^{23}$

In many situations, especially with package goods, it can take a long time for research recommendations to be implemented. Surprisingly, from the point of view of practitioners, the more sophisticated the client in packaged goods, the more tortuous is that path, from the commissioning of a research project to an 'outsider' to the acceptance of the results. Part of this behaviour is the experience (intellectual and emotional 'baggage') brought to the business by the client familiar with research programmes. Such familiarity often breeds disinterest, because the marketer has already been exposed to many competing research approaches. Since the performance feedback cycle from the marketplace is long, it is no wonder that the typical marketer view is so jaded. There is simply not enough time to connect research results with market performance.

Direct television marketing is very different in this regard. The lack of ongoing application of sophisticated research and analysis techniques was, at first, viewed as a negative by research firms because marketers were not initially aware of different available procedures. Infomercials have a very rapid feedback cycle, however. Either the product sells or it does not sell. The marketer discussed in this paper was able to observe the outcomes of each research effort based upon the ultimate look and feel of the infomercial, and upon marketplace results. This fast feedback was important in helping the marketer make a judgment regarding the research process. Another factor contributing to this success was experience. The marketer had worked with many different types of products, all of which needed to be screened, with promising ones optimised for features and communications. Experience with a plethora of different items from vastly different product categories ensured that the marketer would not fall into the trap of relying primarily upon a single

product category and standardised sources of knowledge.

In direct marketing television, where audiences require constant change in the presentations of products as well as product features, the stimuli are physical changes such as product offerings and attributes. The fast feedback cycle - 30 minutes from infomercials to sales orders (or lack of) — virtually guarantees that the complacent marketer, even with a solid set of products, will not engage viewers' attention and will lose competitive edge.

The rapid feedback cycle, ever-changing product sets, the need for 
speed in the conclusion of research and development efforts, and concrete application of these results in the formation of infomercials all contributed to generate marketer interest in standardising higher-level research methods for future projects. Of particular interest in this study was the fact that the initially unsophisticated marketer was able to integrate these methods into the marketing effort to far greater effect than were the more sophisticated marketers. The marketers worked in categories where the feedback cycle was long, where there was a great deal of inertia in the development efforts of truly creative product concepts and where product array was limited. In a sense, the paradigm for the development cycle echoes the call to do "the right thing, in the right way, at the right time, for the right cost'. ${ }^{24}$

\section{References}

1 Cattin P. and Wittink, D. R. (1982) 'Commercial use of conjoint analysis: A survey', Journal of Marketing, Vol. 46, pp. 44-53.

2 Wittink, D. R. and Cattin, P. (1989) 'Commercial use of conjoint analysis: An update', Journal of Marketing, Vol. 53, pp. 91-96.

3 Green, P. E. and Srinivasan, V. (1978) 'A general approach to product design optimization via conjoint analysis', Journal of Marketing, Vol. 45, pp. 17-37.

4 Griffin, A. (1997) 'PDMA research on new product development practices: Updating trends and benchmarking best practices', Journal of Product Innovation Management, Vol. 14, pp. 429-458.

5 Hooper, R. and Jones, C. (1998) 'Lean operations - The route to competitiveness', British Telecommunications Eng, 17th April, Part 1, pp. 2-9.

62000 Economic Impact (6th edn.), US Direct Marketing Today - Executive Summary, Key Definitions, Direct Marketing Association, p. 2.

7 Gardner, B. B. and Levy, S. J. (1995) 'The product and the brand', Harvard Business Review, Vol. 33, March-April, pp. 33-39.

8 Hultink, E. J. and Robben, H. S. J. (1996) 'Measuring product development success and failure', in Rosenau et al. (eds) 'The PDMA Handbook of New Product Development', John
Wiley, New York, NY, pp. 455-460.

9 Moskowitz, H. R. (1998) 'Designing new products in cyberspace - research driven innovation', CASRO Annual Journal, Port Washington, NY, pp. 69-78.

10 Moskowitz, H. R. and Martin, J. G. (1993) 'How computer aided design and presentation of concepts speeds up the product development process', Proceedings of the 46th ESOMAR Conference, Copenhagen, Denmark, pp. 405419.

11 Box, G. E. P., Hunter, J. and Hunter, S. (1978) 'Statistics for experimenters', John Wiley, New York.

12 Ibid.

13 SYSTAT (1994) 'Systat, The System for Statistics', Systat Corporation, Evanston.

14 Moskowitz, H. R. (1996b) 'Segmenting consumers on the basis of their response to concept elements: An approach derived from product research', Canadian Journal of Market Research, Vol. 15, pp. 38-54.

15 Jain, A. K., Acito, F., Malhorta, N. K. and Mahajan, V. (1979) 'A comparison of the internal validity of alternative parameter estimation methods in decompositional multiattribute preference models', Journal of Marketing Research, August, pp. 313-22.

16 Green, P. E. and Krieger, A. M. (1991) 'Segmenting markets with conjoint analysis', Journal of Marketing, Vol. 55, pp. 20-31.

17 Mitchell, A. (1983) 'The nine American lifestyles', MacMillan, New York.

18 Moskowitz, H. R. (1996a) 'Segmenting consumers world-wide: An application of multiple media conjoint methods', 49th ESOMAR Congress, Istanbul, pp. 535-552.

19 Moskowitz (1998) op. cit.

20 Moskowitz, H. and Rabino, S. (1994) 'Sensory segmentation: An organizing principle for international product concept generation', Journal of Global Marketing, Vol. 8, pp. 73-93.

21 Golden, L. L. and Johnson, K. A. (1982) 'The impact of sensory preference and thinking versus feeling appeals on advertising effectiveness', in Bagozzi, R. P. and Tybout, A. M. (eds) 'Advances in Consumer Research', Vol. 10, Proceeding of the Association for Consumer Research, pp. 203-208.

22 Veganti, R. (1997) 'Leveraging on systemic learning to manage the early phases of product innovation projects', RED Management, Vol. 27, No. 4, pp. 377-392.

23 Srinivasan and Chan Su Park (1991) 'Suprising robustness of the self-explicated approach to customer preference structure measurement', Journal of Marketing Research, Vol. 55, October, pp. 20-31.

24 Nuese, C. J. (1995) 'Building the right thing right: A new model for product technology development', Quality Resources. New York, NY. 